\title{
Topografía de los sentimientos, intertextualidad y programas iconográficos en Julieta (Pedro Almodóvar, 2016)
}

\section{Topography of the Emotions, Intertextuality, and Iconographic programs in Julieta (Pedro Almodóvar, 2016)}

\author{
Pedro Poyato \\ Universidad de Córdoba, España \\ pedro.poyato@uco.es \\ https://orcid.org/o000-0003-2511-5392
}

\section{Resumen:}

Aun cuando ciertos estudios críticos han dado por sentado que con Julieta nace un Almodóvar nuevo, un Almodóvar menos almodovariano, la escritura del filme trabaja las mismas constantes visuales y narrativas de películas anteriores. El objetivo de este trabajo es la catalogación y el estudio de esas constantes, desde el modo de formalización del relato y la incorporación al mismo de nuevos intertextos, tanto escultóricos, como pictóricos y arquitectónicos, hasta la irrupción y proliferación de las cocinas como lugares configuradores de un mapa topográfico-sentimental de la protagonista, y el trazado de singulares iconografías en torno al sexo y al rostro femenino.

\begin{abstract}
:
Even when certain critical theoreticians have claimed that Julieta opens a new Almodóvar era, a less almodovarian period, the film writing revisits the same visual and narrative themes of previous works. The aim of this paper is to study and classify those themes, from way the story is formalized and new intertexts -sculptural, pictorical, architectural- are added, to the irruption and proliferation of the kitchen as the place-origin of an emotional, topographic map of the protagonist, as well as the shaping of unique iconographies around the idea of sex and female visage.
\end{abstract}

Palabras clave:

Cine; Almodóvar; Cocina; Intertextualidad; Iconografía.

Keywords:

Film; Almodóvar; Kitchen; Intertextuality; Iconography. 


\section{Introducción}

A pesar de que cierta crítica, alentada por el propio director del filme, haya tendido a ver en Julieta un Almodóvar nuevo, un Almodóvar menos almodovariano ${ }^{1}$, lo cierto es que este filme, al igual que sus antecesores - se exceptúa Los amantes pasajeros (2014)-, esos que han sido agrupados bajo la denominación de “drama cinematográfico almodovariano” (Poyato, 2015, p. 9), sigue estructurándose -al margen de que, como puntualiza el cineasta, su manera de acercarse a la historia venga ahora presidida por la discreción ${ }^{2}-$ en torno a unas mismas constantes, tanto narrativas como visuales. Entre estas se cuentan, además de las ya consabidas operaciones de transtextualidad, uno de cuyos paradigmas, la intertextualidad, Julieta continúa enriqueciendo con la introducción de nuevas variantes, y de la conjugación de capas temporales y voces narradoras, en este caso desplegadas a partir de la escritura de la carta de una madre a su hija ausente, la incorporación de las cocinas como lugares estratégicos tanto del espacio doméstico como narrativo, y la creación de imágenes singulares destinadas a la conformación de un programa iconográfico en torno al sexo, por un lado, y al trazado visual del rostro protagónico femenino encarnado por dos actrices diferentes, por otro. Apoyándonos en las metodologías establecidas por André Gardies para el estudio del espacio en el cine, y por Pedro Poyato en su texto sobre identidad visual y forma narrativa en el cine de Almodóvar, en lo que sigue estudiamos estas constantes antes citadas, desde la presencia de las cocinas y su importancia en el trazado cartográfico de los sentimientos, y los distintos intertextos incorporados, hasta la conformación de nuevas iconografías en torno al sexo y al rostro. Se trata de rendir así cuentas de la génesis y funcionamiento de todas ellas en esta película, Julieta, la número veinte del cineasta manchego.

1 Así, Esteban Ramón, en entrevista realizada a Almodóvar el 4 de abril, apunta que "se habla de Julieta en términos de poco almodovariana" (Ramón, 2016, s/p). Por su parte, Luis Martínez, también en una entrevista realizada al director manchego, interrogaba a éste en los siguientes términos: "¿Por qué esa voluntad explícita de borrar cualquier atisbo de Almodóvar en la película número 20 de Almodóvar?”, a lo que el director respondía: "Me alegro de que se note", añadiendo: "Con Julieta nace un nuevo camino; una nueva deriva..." (Martínez, 2016, $\mathrm{s} / \mathrm{p})$.

2 "Esta historia trata del dolor y enseguida vi claro que para acercarse a ésta la única manera es la discreción" (Martínez, 2016, s/p). 


\section{La cocina como topónimo. Mapa topográfico sentimental del filme}

Las cocinas son el sanctasanctórum de las casas. Antes me gustaba decir esa boutade de que en una cocina nunca se miente. Lo cierto es que en ellas siempre ocurren muchas cosas. Son lugares balsámicos... (Fernández-Santos, 2016, p. 24)

Cuando no reducidos a un mero trasfondo que arropa la intervención de los personajes, los distintos lugares hogareños que aparecen en un filme se ven por lo general recluidos a una mera representación funcional que los convierte en espacios destinados a dormir, charlar, cocinar, comer, etc. En el cine de Almodóvar, sin embargo, estos lugares no quieren ser un mero pretexto funcional, sino que, resistiéndose a ser eclipsados por la actuación del personaje, se alían con él para proclamar así su existencia. La cocina se descubre como uno de esos lugares, especialmente en Julieta, donde va a multiplicarse extraordinariamente, según una proliferación destinada a convertir cada una de ellas en un espacio de llamativa escenografía vinculado a las vicisitudes dramáticas y sentimentales del personaje que lo habita o transita.

Según el diccionario de uso del español, la cocina es "una habitación de la casa dispuesta con las instalaciones necesarias para guisar y realizar las operaciones complementarias para la preparación y servicio de las comidas" (Moliner, 2001, p. 661). En tanto que zona destinada a una función particular, la cocina es, en los términos establecidos por André Gardies (1993, pp. 78-86), una categoría de lugar que, dependiendo de cómo sean, por ejemplo, sus instalaciones, puede presentar una amplia gama de variantes. Las cocinas de Julieta se descubren, así, como lugares polifuncionales -los personajes no sólo preparan y sirven en ellas las comidas, sino que también se reúnen allí, conversan, toman decisiones importantes, confiesan sus intimidades, e incluso se detienen a contemplar el mar- que, atendiendo a su localización y amueblamiento, presentan hasta un total de cinco variantes. Esta proliferación nos interesa, sobre todo, por dos motivos: primero, porque las cocinas se descubren, todas ellas, como los lugares del filme que con más intensidad participan en la diégesis -y es que, como bien dice Almodóvar en la cita anterior, en ellos ocurren muchas cosas- hasta el 
punto de constituirse en auténticos centros nucleares del relato; y segundo, por que configuran un mapa tanto topográfico, al estar cada cocina vinculada a un topónimo que viene dado por la ubicación geográfica de la vivienda de la que forma parte, como biográfico-sentimental, al corresponderse el tránsito que la protagonista, Julieta (Adriana Ugarte / Emma Suárez), va haciendo por cada una de ellas 3 con otras tantas etapas o momentos cruciales -y dramáticos- de su vida. Nos encontramos así con un ejemplo de topografía en la que los topónimos no sólo entran en correspondencia entre sí, sino que ofrecen elementos de dramaturgia relacionados con el trayecto vital del personaje principal del relato, Julieta.

En el viaje por la geografía española que baliza su vida, Julieta pasa sucesivamente, a lo largo de la historia que el filme cuenta, por las siguientes viviendas: la casa de Redes (A Coruña), donde vive Xoan (Daniel Grao), que acabará convirtiéndose en su hogar; el caserío andaluz de La Cansina donde viven sus padres, hasta donde Julieta se desplaza para visitarlos; el piso en pleno centro de Madrid de los padres de Bea, la amiga de su hija Antía (Priscilla Delgado), a quienes Julieta cumplimenta; el piso sito en la también madrileña calle Fernando VI, $\mathrm{n}^{0}$ 19, el segundo hogar de Julieta, tras la muerte de Xoan; otro piso sin dirección conocida, pero igualmente ubicado en zona céntrica de Madrid, al que Julieta se traslada huyendo de los recuerdos de Antía; y finalmente, el inmueble ubicado en el mismo bloque de Fernando VI, 19, aunque en una planta distinta del piso anterior. Y bien, en cinco de estas seis viviendas -se exceptúa la última de ellas, donde Julieta ocupa el tiempo en escribir una carta a su hija Antía-, la cocina se descubre como el lugar más importante de la casa, el sanctasanctórum, que dice Almodóvar, tanto por su atrezzo cuanto por que en cada una de ellas van a tener lugar, como antes apuntaba, situaciones narrativas y dramáticas nucleares.

\footnotetext{
3 Jean-Claude Seguin (2009, p. 68) refería cómo las cocinas almodovarianas tienen que ver con lo transitorio, lo fluido, los flujos, en el sentido de que en ellas las figuras no se paran, apenas se detienen. Pues bien, Julieta lleva al límite esta máxima.
} 


\subsection{Redes y Huerta La Cansina. Espacios de la modificación, de la acumulación, de la incertidumbre y de la tensión}

Atendamos ahora a cómo esas viviendas van siendo sucesivamente introducidas en la historia -no en el relato- que el filme cuenta: tras el primer encuentro con Xoan en un tren, Julieta responde a la invitación de este acudiendo hasta su casa, en Redes. Allí es recibida por la sirvienta, Marian (Rossy de Palma), quien la invita a pasar, pero no al recibidor, el lugar más apropiado para un invitado, sino a la cocina, que se constituye ya a partir de aquí en lugar esencial de la vivienda, no tanto por que en ella se prepare el café con que va a ser obsequiada la visita -dimensión funcional-, cuanto por su llamativa escenografía dimensión visual- en la que destacan los azulejos blancos decorados con motivos marinos de conchas y peces de color azul, el mobiliario también blanco, a excepción de las sillas, de color rojizo a juego con el tapete rojo y blanco de la mesa y, sobre todo, el gran ventanal desde el que se percibe, imponente en su majestuosidad, el mar azul (F1). Tal es el combinado cromático de un lugar que

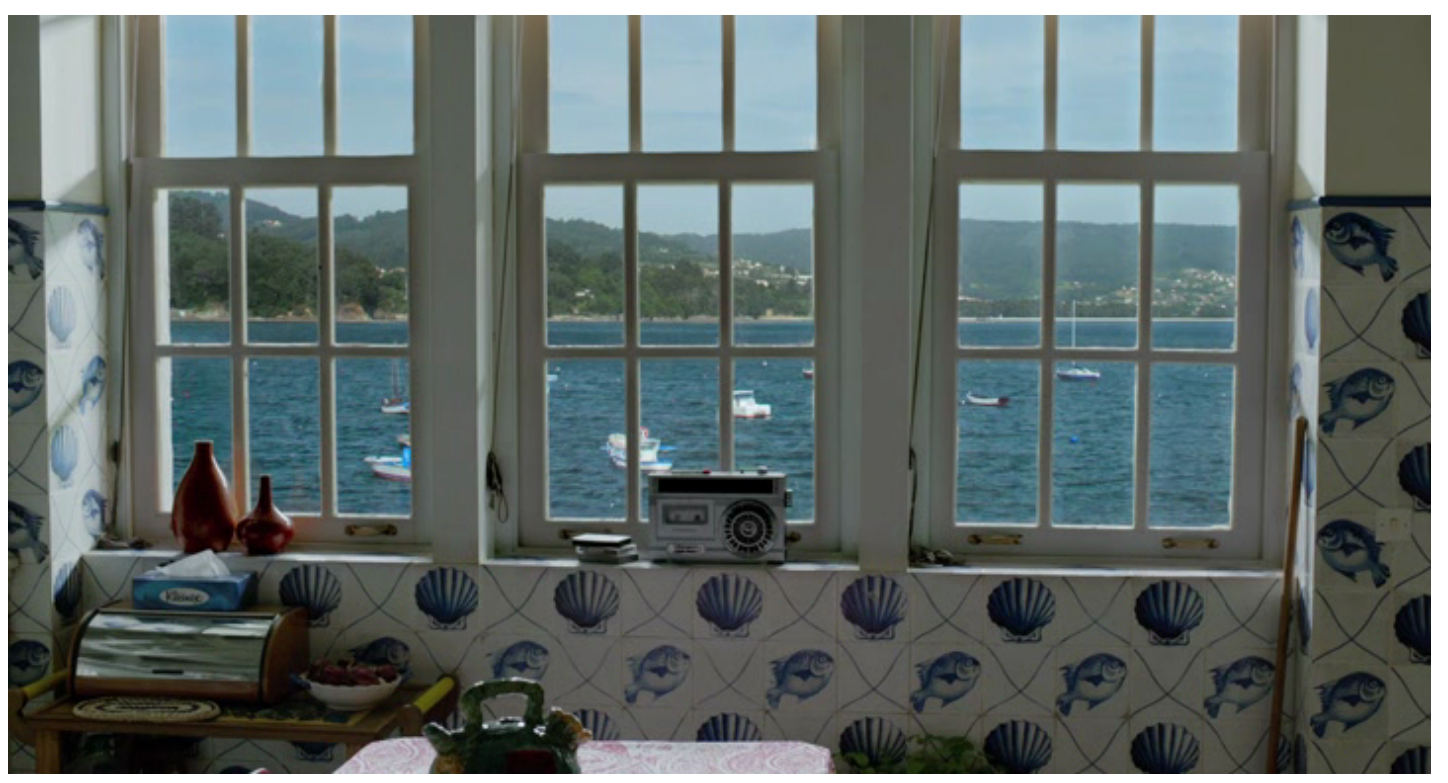

F1. Julieta (Pedro Almodóvar, 2016). El Deseo

deviene además en espacio de confidencias entre los personajes -dimensión narrativa-: si nada más entrar en la cocina, Marian anuncia a Julieta que Xoan pasa las noches con una amiga íntima, Ava (Inma Cuesta), a la mañana siguiente, este mismo espacio, ahora visualmente enriquecido con la presencia de una fuente multicolor de frutas, es testigo de una conversación en la que 
Xoan pide a Julieta que permanezca a su lado unos días más. La cocina se descubre, pues, como espacio de la modificación por cuanto los personajes, además de preparar y degustar en ella las comidas -el café y los desayunos-, acaban tomando decisiones que van a cambiar su vida, como es el caso de Julieta, quien decide iniciar una relación sentimental con Xoan en la que, como fue anunciado por Marian, Ava no va a estar exenta de protagonismo.

En un segmento posterior, Julieta visita con la pequeña Antía a sus padres, quienes viven en Huerta La Cansina, una casa ubicada a las afueras del sevillano pueblo de Mairena del Alcor. También aquí, en este vistoso caserío de dos plantas del siglo XIX, la cocina se descubre como un lugar visualmente muy llamativo por su trazado escenográfico y cromático: pintadas las paredes de un blanco salpicado por el azul de dos estanterías, sobresalen en ella los verdes, localizados tanto en los cuadros del hule de la mesa - a juego con los azules de la camisa del padre de Julieta-, como del perejil, en segundo término, y de las hortalizas que rebosan en la banasta que asoma por la parte inferior izquierda del cuadro, y los rojos tanto del listado de las cortinas del fregadero como de los tomates (F2) 4 . Las ristras de ajos y de pimientos secándose que penden del techo introducen la nota rústica en una imagen que caracteriza esta cocina como lugar de la abundancia y de la acumulación, pero también de la anarquía

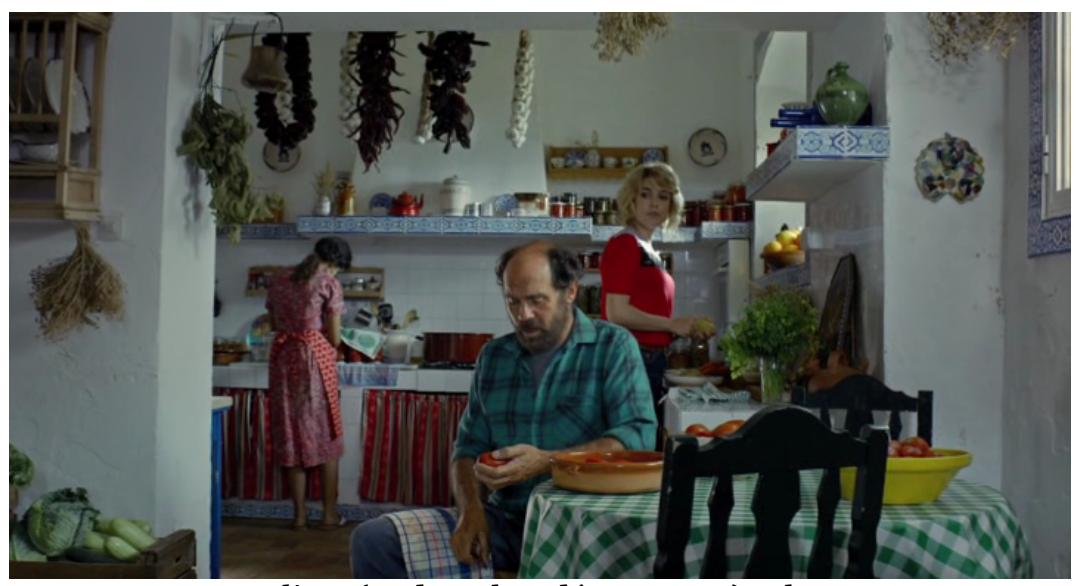

F2. Julieta (Pedro Almodóvar, 2016). El Deseo

4 El mismo cineasta ha señalado que, aun cuando la paleta es distinta a otras películas, sigue inclinándose en Julieta por colores contrastados y vivos, y añade: "Es mi naturaleza. Por un lado, pienso siempre en el impacto visual. Si hago un plano corto ahora contigo -dice al entrevistador-, lo que más aparece es el color de la silla, el color de tu camiseta y el color de la pared. El suelo y la pared se convierten en elementos protagónicos de lo visual. Y los muebles y los trajes. Lo ensayo todo como un pintor" (Ramón, 2016, s/p). 
propia de las cocinas campesinas. La conversación que Julieta mantiene a solas con su padre (Joaquín Notario) transcurre en este mismo espacio de la cocina, donde los ajos, los pimientos rojos y verdes y los tomates se mezclan entonces con las palabras de Julieta reprochándole a su padre la poca atención que presta a su madre (Susi Sánchez), convertida en poco más que una fría presencia, a la vez que le recrimina su relación íntima con Sanáa (Mariam Bachir), la chica que hace las labores del hogar y que le ayuda en el campo. Al igual que sucediera en la casa de Redes, la cocina se descubre, también aquí, como un topónimo en el que, más que en cualquier otro espacio del caserío, los personajes se cruzan y encuentran para decirse las cosas a la cara, para verbalizar situaciones delicadas, referidas en este caso a la relación que mantienen los padres de Julieta5. Relación, por demás, que presenta una cierta simetría con la antes generada en Redes, por cuanto del mismo modo que la presencia de Ava contamina la relación entre Xoan y Julieta, la de Sanáa hace lo propio con la de los padres de Julieta. Triángulos sentimentales y familiares estos que presentan, además, el añadido de un cuarto vértice, representado en ambos casos por la presencia de una hija única, Antía, allí, y la propia Julieta, aquí.

En una escena posterior, de nuevo en la casa de Redes, Xoan acaba confesando a Julieta sus devaneos sexuales con Ava. La tormenta sentimental entonces desencadenada no tarda en extenderse a la meteorología, como así lo anuncia un viento cada vez más huracanado, pero que sin embargo no impide que Xoan salga a pescar. La fuerza del viento tiñe de negro el cielo de nubes y agita el mar desencadenando olas de gran intensidad. No tarda en llover copiosamente. Un plano nos sitúa entonces ante el gran ventanal de la cocina desde donde vemos el oscuro cielo ciñéndose en torno al mar embravecido. Sobre el plano, Julieta entra en cuadro ubicándose delante del ventanal, de espaldas al espectador, hasta componer una imagen (F3) que conjuga lo próximo -ella- y lo lejano -el

\footnotetext{
5 En este sentido, la relación, aun cuando todavía incipiente, entre Sanáa y el padre de Julieta ha sido sin embargo ya bien caracterizada tanto a través de las miradas cómplices que ambos intercambiaban durante el viaje en coche, tras recoger a Julieta y su hija en la estación de autobuses, como, sobre todo, en el modo de llevar Sanáa el cochecito de la pequeña Antía, en el corto recorrido a pie hasta el caserío. Más adelante, una llamada telefónica a Julieta será el pretexto para que nos enteremos de que, muerta la madre, la pareja se ha casado y son padres de un pequeño.
} 
mar-, el interior doméstico -la cocina- y el exterior salvaje -la fuerte tormenta, el mar embravecido-; dialécticas, ambas, emanadas del enfrentamiento de tintes románticos entre el individuo, que este caso cobra la

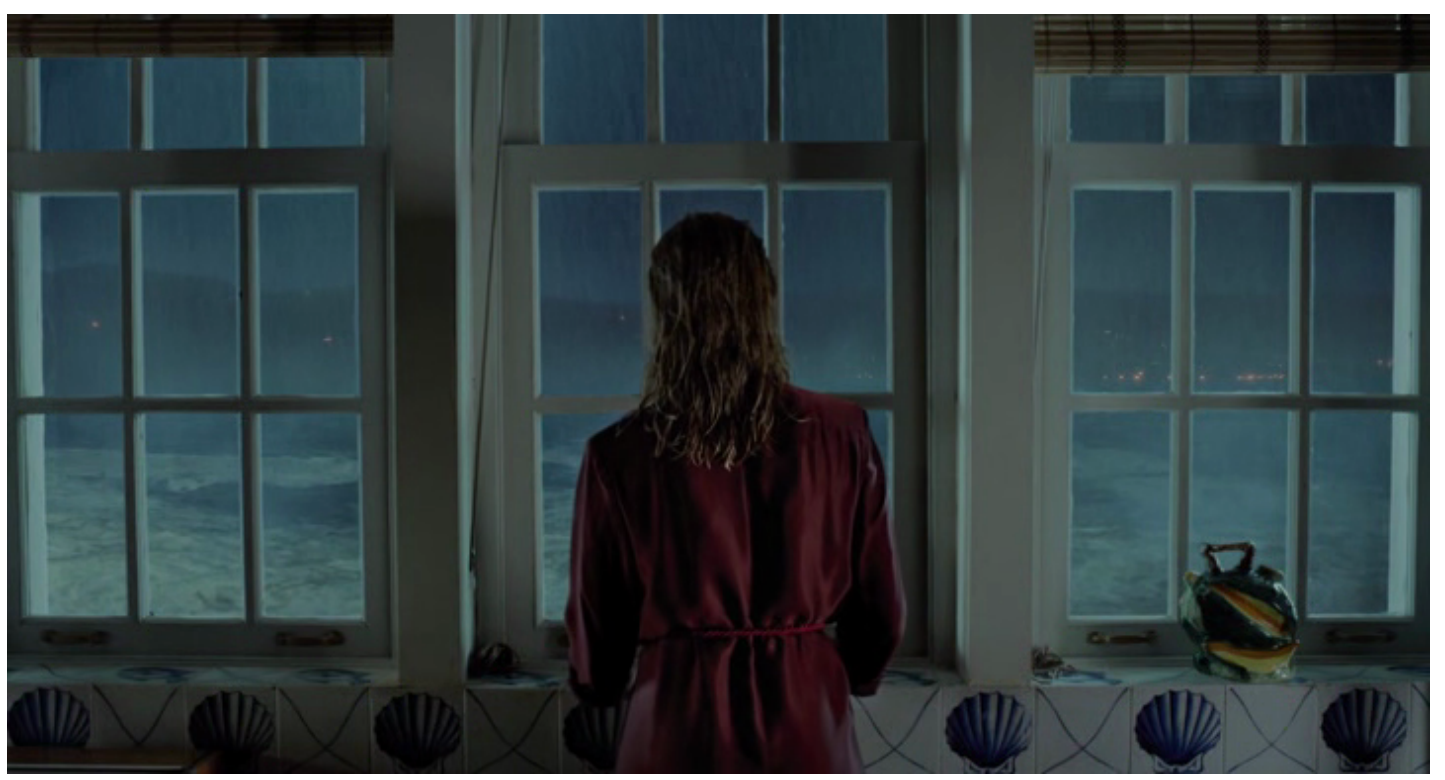

F3. Julieta (Pedro Almodóvar, 2016). El Deseo

forma de una silueta femenina, y la naturaleza, que le desborda. La representación de la mujer de espaldas mirando a través de la ventana, motivo iconográfico recurrente en la historia de la pintura, es trasplantada de este modo al cine siguiendo un esquema composicional plasmado en tres registros rígidamente separados: la cocina, interior donde se encuentra la mujer; el ventanal; y el espacio exterior, según una fría delimitación de iconos que "contribuye a potenciar la tensión psicológica del cuadro" (Bastida de la Calle, 1996, p. 311). Tensión que en este caso no tarda en transmitirse a la escena en su conjunto, como así viene a corroborarlo el plano siguiente, un contraplano del anterior en el que puede verse el rostro de Julieta desde el otro lado del ventanal ${ }^{6}$. Y así, si antes esta cocina devenía en espacio de la modificación, ahora lo es de la incertidumbre y de la tensión, como así lo acusa, en su expresión, el rostro de la mujer.

6 Plano que puede ser puesto en relación con el que cierra Calle Mayor (Juan Antonio Bardem, 1956), donde el rostro de Isabel, la protagonista del filme, inscribía, también en su mirada a través del cristal de la ventana, el drama de la mujer, por mucho que se trate de dos dramas muy diferentes entre sí, como muy diferentes son las causas a las que responden. 
Pero, al igual que las escenas anteriores, en esta tampoco falta el combinado cromático, que ahora emana de los colores de la comida que Julieta prepara para la cena: ensalada de brotes verdes y tortilla francesa. El hecho de que veamos planos detalle focalizados desde un punto de vista cenital de los alimentos que están siendo cocinados origina una suerte de imágenes casi abstractas interesadas sólo por conjugar colores: los verdes de las hojas de la ensalada salpicados del marrón de las nueces, y el amarillo intenso de la yema del huevo batido cocinándose en la sartén. Esta intensificación de la paleta cromática, unida a la estilización de las imágenes anteriores de la mujer en la ventana, es ahora antecedente de la fatal noticia de la desaparición de Xoan, tragado por ese mar embravecido avistado por la mujer. Imágenes todas ellas que convierten de nuevo a la cocina en espacio nuclear del relato, en este caso por vestir un acontecimiento que va a marcar a fuego el devenir vital de Julieta.

\subsection{Madrid. Espacios de la decisión, de la pérdida y de la modificación}

La siguiente casa a la que acude Julieta está ubicada en el Madrid céntrico y es propiedad de los padres de Beatriz, la amiga de Antía. También en esta ocasión la cocina deviene en lugar esencial para los intereses del relato: como si de un imán se tratara, los personajes acaban encontrándose en ella. Se trata ahora de una cocina tan espaciosa y equipada como la de un restaurante, como de ello da cuenta el único plano que articula la escena, donde vemos a Julieta conversando con la madre de Beatriz (Pilar Castro), ambas en primer término, mientras que al fondo, tintados en esta ocasión del color grisáceo de lo metalizado, aparecen los fogones, en ellos cocinando de espaldas al espectador la tata Rosa, personaje interpretado por la famosa peletera Elena Benarroch, dueña por lo demás de esta espléndida casa del centro de Madrid. Tan singular incorporación al filme de la cocina y de Benarroch, además de constituirse en un homenaje de Almodóvar a su amiga, viene a reforzar el atractivo de este espacio del relato en el que se cruzan las figuras y se forjan los destinos, en este caso por ser determinante para el traslado de residencia de Julieta y su hija a Madrid.

Y así, poco después, vemos a Julieta en su nuevo hogar sito en la calle Fernando VI, $n^{0} 19$, de Madrid; un piso en el que la cocina no tarda en hacerse presente en 
las imágenes, esta vez con motivo de que hasta ella sean convocadas madre e hija por un asunto narrativamente irrelevante, la preparación de un sándwich. Tal es el pretexto para que atendamos a la escenografía, presidida una vez más por el cromatismo, en este caso emanado de la conjugación del amarillo del alicatado con el azul y marrón del mobiliario de madera. Y poco después, con motivo en esta ocasión de la carta que Julieta redacta a su hija, vuelve a aparecer la cocina y, en ella, Julieta probando la comida que está cocinándose al fuego, imágenes sobre las que oímos la voz over de Julieta refiriendo la partida de Antía a un retiro en los Pirineos, en un viaje que a la postre se descubrirá definitivo por cuanto va a conllevar la desaparición sin dejar rastro de Antía. Nos encontramos así con una acción - probar la comida que se está cocinandonarrativamente irrelevante -ninguna función va a desempeñar esa sopa en el transcurso del relato- y desconectada, además, de lo narrado en ese momento por la voz over de Julieta, lo que viene a demostrar el interés del filme, yuxtaponiendo la imagen invocada del pasado y la voz over en presente, por introducir la cocina allí donde Julieta se ve inmersa en acontecimientos tan dramáticos como determinantes en su vida.

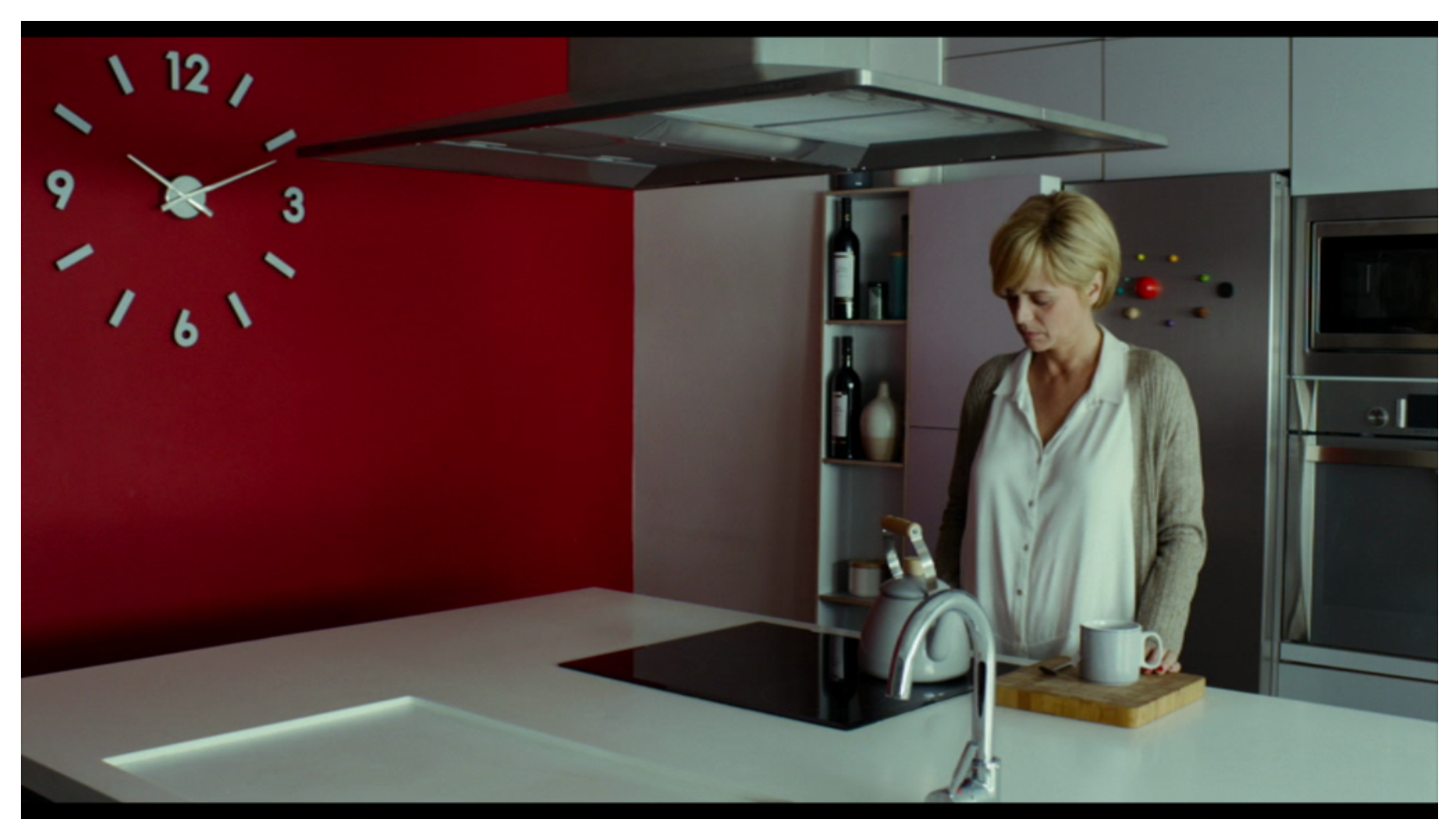

F4. Julieta (Pedro Almodóvar, 2016). El Deseo

Precisamente, el no retorno de Antía de este viaje a los Pirineos acabará desencadenando en una Julieta (Emma Suárez) transida por el dolor el deseo irrefrenable de borrar cualquier huella de su hija para tratar de combatir así ese 
dolor. Es entonces cuando Julieta opta por cambiar de piso. Una vez más, en las imágenes de la nueva vivienda, la cocina adquiriere enseguida relevancia tanto por su escenografía como por su carga dramática. Se trata ahora de una cocina de diseño, con muebles lacados minimalistas, aséptica de tan limpia, y en la que el cromatismo de las anteriores se ha desvanecido (F4). Se diría, así, que las gamas cromáticas de las cocinas anteriores han dado paso a una presencia más densa de las líneas, de la geometría, según un trazado que acerca el nuevo espacio a la abstracción. Una cocina, pues, diferente, con un trazado visual acorde con el borrado de huellas demandado por la protagonista, y que viene a reforzar esa íntima relación que, como el filme ha venido trabajando, se establece entre la figura y el lugar, entre Julieta y las distintas cocinas por las que ha venido transitando en su periplo vital. Pero a la vez, y como sucediera con alguna anterior, esta nueva cocina no tarda en descubrirse como espacio de la modificación, por cuanto es en ella donde Julieta anuncia a Lorenzo (Darío Grandinetti) que no viajará con él a Portugal, en una decisión que acarrea la ruptura de la pareja. Más adelante descubriremos que ello viene motivado por el encuentro casual de Julieta con Beatriz, lo que desencadena en aquella el deseo irrefrenable de volver sobre sus propios pasos con vistas al encuentro con (los recuerdos de) su hija. Y así, si antes Julieta dejaba el piso de Fernando VI $\mathrm{n}^{\mathrm{o}} 19$ huyendo de las huellas de Antía, ahora retorna a él tratando de reencontrarse con ellas. Pero no será exactamente en el piso anterior, sino en uno de otra planta del mismo edificio donde Julieta se entregue a la búsqueda de los recuerdos de Antía redactando para ella esa carta ya referida sobre la que se edifica una buena parte del filme. Un piso destinado, pues, a la soledad de la escritura, y por ello ajeno en este caso a la cocina7.

\section{Operaciones de transtextualidad: intertextos}

Una de las prácticas discursivas que animan las películas de Almodóvar es sin duda la transtextualidad, práctica que se prolonga también en Julieta. El hecho de que el filme se construya, como señalan los créditos finales, a partir de tres

\footnotetext{
7 Sin duda es este el motivo por el que no está disponible el mismo piso anterior, pues no interesa ya de él la cocina, tantas veces protagonista cuando Julieta lo habitara, sino el salón, destinado a la escritura, como enseguida podrá comprobarse.
} 
relatos cortos de Alice Munro incluidos en el volumen Escapada, a saber Silencio, Pronto y Destino, permite que el mismo pueda ser estudiado como hipertexto de los textos literarios anteriores, o hipotexto. Sin embargo, no pretendemos ocuparnos ahora de este tipo de transtextualidad ${ }^{8}$, sino de ese otro que de manera recurrente -y que a la postre resulta decisivo en la construcción del discurso- vienen trabajando los filmes almodovarianos: la intertextualidad, y más concretamente la cita intertextual. El propio Almodóvar lo significaba en una entrevista reciente:

Yo, como narrador, me he nutrido de obras de arte de otros, por supuesto. Y muchas veces me han dado la clave de mis guiones. Es verdad que, para encontrar esos momentos, tienes que tener paciencia [...] Y, en esa espera que yo siempre me doy, de pronto llega una canción con un significado distinto, lees un libro... Sí, el arte en muchas ocasiones ha venido para completar, darle forma, fuerza y sentido a la historia que yo estaba escribiendo. (Bermejo, 2016, p. 86)

En efecto, Julieta se descubre como un texto atravesado por la presencia de otros en torno a los que se despliegan operaciones que se quieren acordes con el engranaje del relato, pero que en todo caso resultan decisivas en el forjado de la identidad visual del filme. En este sentido, cada película de Almodóvar puede ser considerada como una apuesta acerca de qué citas incorporar y cómo trabajarlas con vistas a la creación de nuevas formas cinematográficas en las que, además de leerse los significados que encierran, pueda percibirse una identidad visual propia. Y esta es también la apuesta de Julieta. Pero antes de entrar en el estudio de esta vertiente intertextual del filme, conviene aludir, aunque sea de pasada, a un fenómeno relacionado con ella: en una escena de La piel que habito, Vera (Elena Anaya) leía un ejemplar de Escapada, de Alice Munro, volumen donde están incluidos, como antes se ha dicho, los relatos cortos en los que se basa Julieta. Operación recurrente está en el texto almodovariano, la misma consiste en arrastrar un determinado motivo desde un filme en el que no pasa de ser mera anécdota, en este caso el libro que lee el personaje, hasta otro filme donde ese motivo acaba germinando, en esta ocasión como uno de los cimientos de la historia contada. Encontramos aquí un curioso procedimiento que, como si de una variante más de trasplante entre dos 
textos se tratara, establece insólitas conexiones -intertextuales- entre los filmes de Almodóvar', en este caso de Julieta con La piel que habito.

\subsection{Escultura sedente de Miquel Navarro: de cita intertextual a objeto emanado de la diégesis}

Sobre el intenso rojo de una tela que palpita, se recorta una de las pequeñas piezas escultóricas sedentes de terracota de Miquel Navarro (F5): se trata de una obra conocida en la que su protuberante falo contrasta con la falta de brazos, ambos cercenados. Tal es la imagen que abre el filme. La escultura es enseguida cubierta por un plástico de burbujas, en un plano que opta por mostrar sólo las manos de quien realiza la acción. No será hasta después, una vez asignado el protagonismo a la escultura sobre fondo rojo, cuando aparezca el personaje, la mujer protagonista del filme, Julieta, quien, vistiendo una llamativa bata de seda roja, ha dejado el envoltorio listo para su traslado. Con su incorporación al filme de Almodóvar, la talla de Miquel Navarro adquiere así, en el arranque mismo de la película, el estatuto de cita intertextual. Una cita que pasa en este caso por dotar a lo citado de una función narrativa, en tanto que su embalaje junto a otros objetos, remite a un traslado, a una mudanza. $Y$ así será, en efecto, si bien no al lugar de destino en principio previsto, Portugal, sino el propio Madrid. Pero esto es otra cuestión.

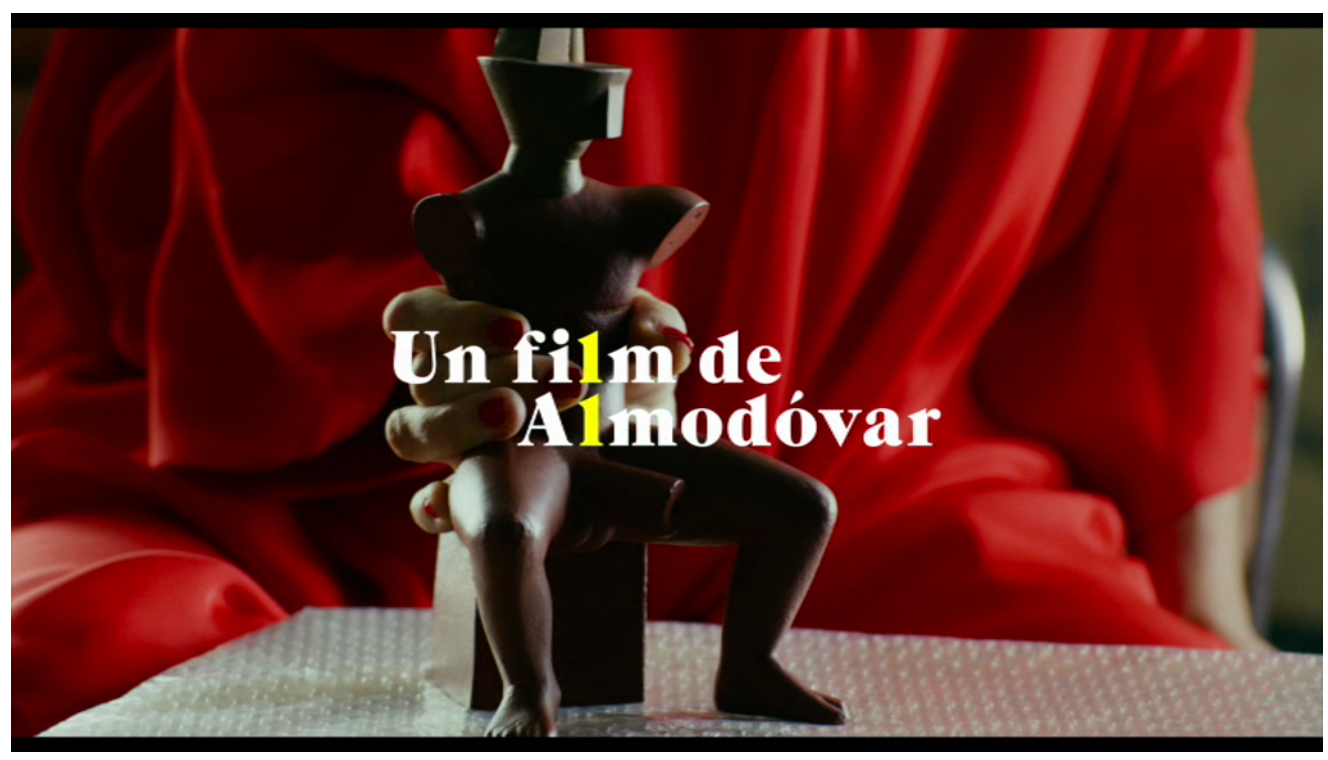

F5. Julieta (Pedro Almodóvar, 2016). El Deseo

9 Para un estudio de este tema, consúltese Poyato (2015, p. 138). 
En todo caso, la operación más importante desplegada en torno a esta cita intertextual es la posterior diegetización de la escultura. Se trata de una operación novedosa, por cuanto el texto almodovariano acostumbra a apropiarse del texto citado para, incorporándolo a sus imágenes, establecer con él determinadas relaciones. De esta manera, el texto citado no pierde su estatuto de exterioridad, esto es, de texto ajeno incorporado al universo del relato. Sin embargo, Julieta, luego de apropiarse de la escultura de Navarro, adornándola con distintos fondos cromáticos -al rojo palpitante y lleno de pliegues del vestido de seda de la mujer le sigue el verde estático con las asperezas propias de la pared en basto donde la escultura es colocada en el nuevo piso-, la descubre, en un segundo movimiento, como emanada del interior mismo del universo narrativo, en una operación que pasa por asignar el rol de escultor a uno de los personajes del relato, concretamente a Ava, la amante de Xoan. El genio creador de Navarro es así transferido a Ava, como puede constatarse en la escena que tiene lugar en el taller de esta ${ }^{10}$ con motivo de la visita de Julieta. Una prolongada panorámica lateral, que tiene su origen en la escena anterior, pasa revista a la obra escultórica de Ava, entre la que se cuenta la escultura sedente que inauguraba el filme, pieza tallada en bronce y cubierta con una pátina de terracota, según explica a Julieta la propia escultora, mientras sus manos modelan en barro otra de las piezas, concretamente los glúteos y las piernas de una mujer echada, de espaldas. Mas se trata de una acción, esta de la escultora, que se descubre pareja a la realizada, en la escena anterior, por la cámara justo donde recorría, como esculpiéndolo, el cuerpo desnudo de Julieta tendida de espaldas, en la cama. Vinculación que se ve reforzada si tomamos en cuenta que esta panorámica anterior sobre el cuerpo de Julieta se prolongaba hasta alcanzar también a Xoan, quien aparecía desnudo, sentado en un sillón, en una postura equivalente a la exhibida por la escultura sedente. Podemos entender ahora este prolongado movimiento de cámara anterior cosiendo ambas escenas por cuanto el filme, orillando la componente narrativa, trata de emparentar así el trabajo del cineasta y el de la escultora justo allí donde ambos, cineasta y escultora, modelan materiales

10 Taller inspirado también en el estudio de Mislata, donde trabaja Navarro. Véase, en este sentido, Labastida (2016, p. 19). 
brutos con el fin de construir formas, en un caso cinematográficas, valiéndose de la puesta en escena y el movimiento de la cámara, y en el otro escultóricas, valiéndose de las manos. Interesante segmento este en el que el propio cineasta quiere medirse, por lo que a la creación artística se refiere, al escultor, en este caso un Miquel Navarro transubstanciado en Ava, uno de los personajes del relato.

\subsection{Autorretrato de Lucien Freud: rostro y mirada}

Colgadas de las paredes de la casa de Madrid, donde Julieta se ha trasladado huyendo de las huellas de su hija Antía, pueden verse tres láminas, dos de ellas son pinturas de Lucien Freud y de Antonio López y la otra recoge un espectáculo del dramaturgo y escenógrafo Robert Wilson. El propio Almodóvar se ha referido a estos carteles en los siguientes términos:

La casa de Julieta pasa de un decorado blanco en los años malos a convivir con tres pósteres que tienen mucho de significado en sí mismos: un autorretrato de Lucien Freud, un espectáculo de Bob Wilson y un cuadro de Antonio López. Antonio es la austeridad [...] sus cuadros son obras maestras, pero es difícil equilibrar un decorado con ellas por su austeridad total. Esas terrazas feas, madrileñas, de barrio, que a mí me apasionan. También quería impregnarme de esa austeridad de Antonio López. Quería que esta película fuera muy contenida. (Bermejo, 2016, p. 86)

Al margen de la más o menos luz que sobre Julieta puedan arrojar estas palabras de Almodóvar emparentando la austeridad de la pintura de López con la de la película, es lo cierto que de las tres láminas anteriores, sólo la del autorretrato de Freud resulta resaltada en las imágenes, pues sólo ella es traída a primer término, a diferencia de las otras dos, que no pasan de ser parte del fondo de imagen. Se trata, como apuntaba Almodóvar, de un autorretrato de Lucien Freud, concretamente el titulado Reflexión (1985). La lámina resulta visualmente muy destacada justo cuando Julieta recupera de la papelera ese sobre de color azul del que poco antes se desprendiera con el ánimo de quien quiere librarse de una pesada carga. Llenando la parte izquierda de la imagen, el retrato de Freud se convierte en uno de sus protagonistas (F6): como puede apreciarse, se trata de un rostro inquietante -en él se dan cita todos los pliegues 
de la carne- cuyos perturbadores ojos parecen mirar a Julieta, rodeándola de este modo de un halo ciertamente conmovedor. Ello tiene que ver sin duda con la acción de Julieta recuperando el sobre para reconstruir la fotografía hecha añicos que contiene. Como pasaba en Los abrazos rotos, el filme se sirve de la recomposición de una fotografía para inscribir la reconciliación de personas con fuertes vinculaciones afectivas, en este caso de Julieta con su hija, Antía. En una imagen posterior vemos la fotografía ya recompuesta, pero sin ocultar sus junturas, metáfora de unas cicatrices de las que va a dar buena cuenta -no por casualidad la fotografía aparece junto al cuaderno donde escribe Julieta- el relato, verdadero motor narrativo del filme, que en forma de carta Julieta redacta a su hija. El dolor que sucesivamente irá aflorando dotará de semblante el rostro de la mujer, un rostro lleno de surcos y, en tanto tal, visualmente no muy alejado del de Freud que poco antes lo miraba ${ }^{11}$.

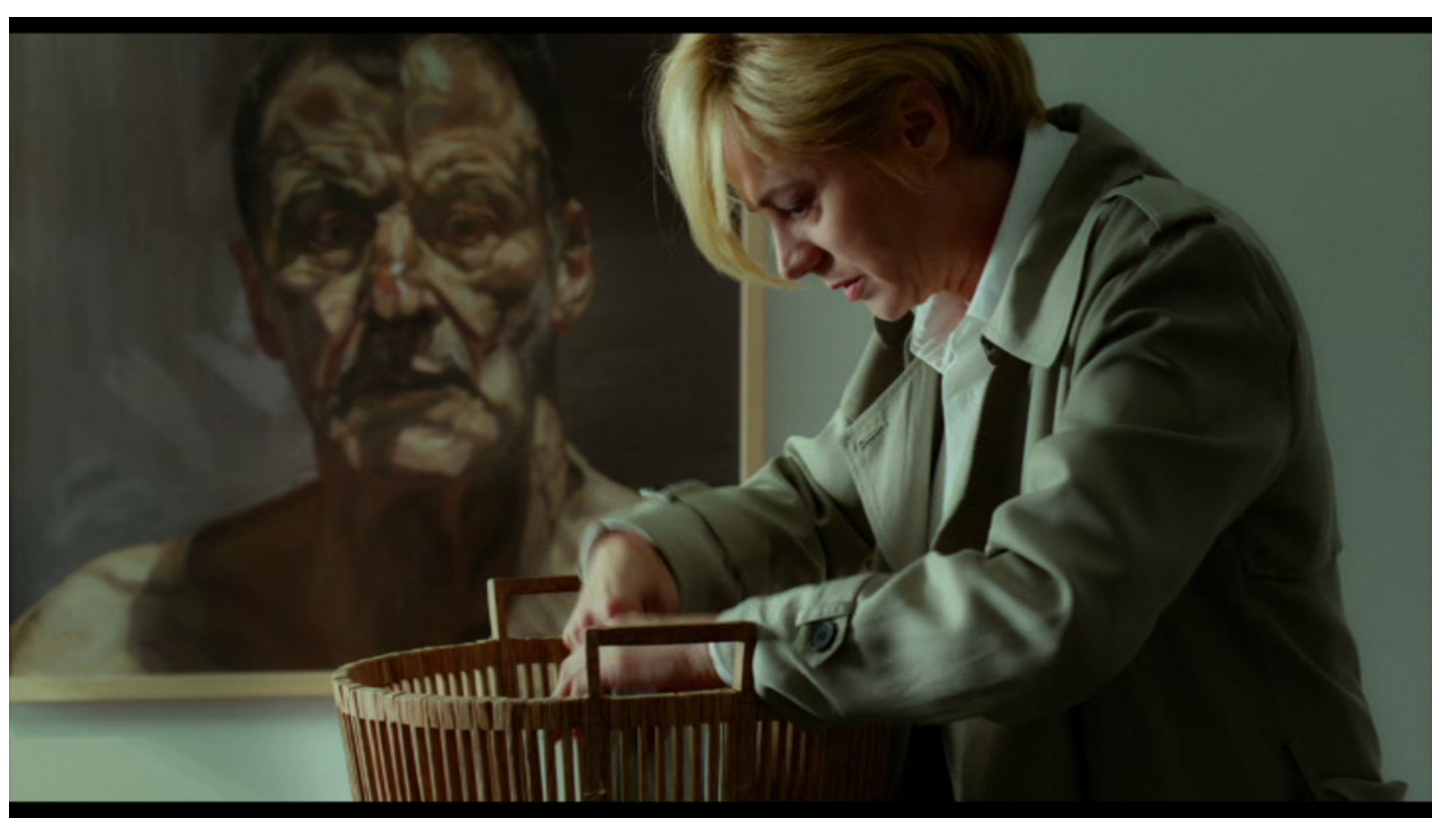

F6. Julieta (Pedro Almodóvar, 2016). El Deseo

11 En efecto, la escritura de la carta se convierte para Julieta en "vehículo para el dolor", en expresión de la escritora colombiana Piedad Bonnett (Zabalbeascoa, 2019, p. 51). Y así lo confirma ese plano detalle que muestra las últimas palabras escritas por Julieta: "Tu ausencia llena mi vida por completo y la destruye", verbalización de cómo esta madre tan sólo se siente viva en el hueco del no-estar de su hija. Viene esto a demostrar hasta qué punto la mujer escribe "desde las tripas", también en expresión de Bonnett, quien, en este sentido, añade: "Las mujeres no hemos tenido la contención del sentimiento que han sufrido los hombres. La madre llorando es la Pietà. El padre llorando ¿̇qué es?” (Zabalbeascoa, 2019, p. 52). 
Tal es, pues, la interesante función desempeñada por el intertexto freudiano: además de introducir una mirada externa sobre Julieta cuando esta recupera el sobre con la fotografía hecha pedazos, auténtico desencadenante del relato fílmico, como se ha dicho, parece irradiar su rictus al personaje, en lo que se refiere tanto al ejercicio de reflexión que para este supone la reconstrucción del rompecabezas, cuanto al dolor a ello asociado. De manera que la cita intertextual de Freud no sólo orna la escenografía de Julieta, sino que, con su incorporación, penetra y enriquece los tejidos del texto: la relevancia de la recuperación del sobre azul con la fotografía-rompecabezas por parte de Julieta no habría sido la misma sin la presencia de la mirada del cuadro de Freud, como tampoco el rostro de Julieta escribiendo la carta a su hija cobraría la misma fuerza visual sin su vinculación a ese otro rostro del cuadro que la miraba.

\subsection{Colegio Estudio de Fernando Higueras: marco espacial}

Una nueva incorporación al texto almodovariano, en este caso de una obra arquitectónica, es el colegio Estudio en Aravaca (Madrid) de Fernando Higueras, una construcción de 1962-63. Heredero del regeneracionismo laico de la Institución Libre de Enseñanza, el colegio Estudio hizo realidad sus ideales pedagógicos y estéticos. El propio Almodóvar ha justificado así su inclusión en el filme:

Hago un homenaje al colegio Estudio y a su historia, que es deslumbrante dentro de nuestra intelectualidad. Pero sobre todo quería homenajear a Fernando Higueras, su arquitecto. Cuando construyó el colegio [...] pensaron que no se iba a poblar, del horror que provocó. En ese momento fue un escándalo. Él era un visionario. Un hombre muy extravagante al que en su momento no se entendió. Localicé montones de rincones que me apasionaban y no pude hacer tantos planos como me hubiese gustado. (Bermejo, 2016, p. 86)

Estas palabras del cineasta caracterizan ya la obra arquitectónica no de cita, sino de homenaje, por cuanto su incorporación no abre el texto a operaciones discursivas en torno a ella, sino que se queda en una agregación que no pasa de convertirla en mero marco espacial, en concreto el lugar donde Julieta imparte sus clases de literatura clásica. El edificio de Higueras, en suma, se incorpora al 
filme no por su rentabilidad como operador textual, sino por la importancia que en su día tuvo como obra arquitectónica, esto es, por una causa externa a los intereses del relato propiamente dicho. Tal es la diferencia entre cita y homenaje. No faltan por eso en el filme planos de la vista más emblemática del edificio, con los retranqueos de fachada que conforman los volúmenes de los distintos pisos, cada uno con terraza y barandillas amarillas (F7).

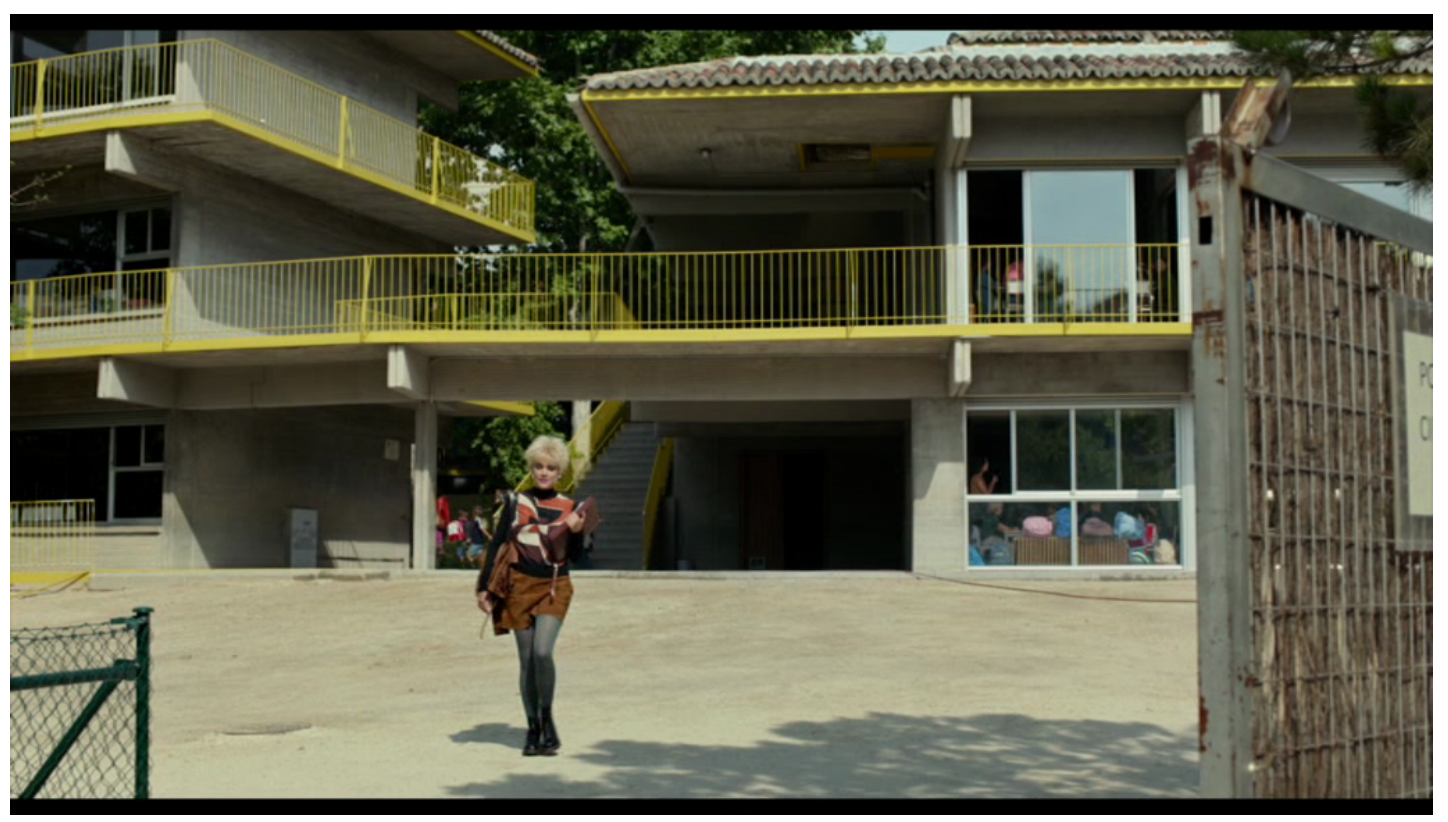

F7. Julieta (Pedro Almodóvar, 2016). El Deseo

Mucho más interesante resulta en todo caso atender a la correspondencia entre el colegio Estudio y Julieta a propósito de los elementos esenciales que Luis Fernández-Galiano ha fijado para caracterizar la obra higueriana, a saber "el rigor geométrico, la empatía con la naturaleza y la expresividad escenográfica” (Fernández-Galiano, 2003, pp. 5-6), elementos extrapolables al filme. Pues en efecto, como en la obra de Higueras, en la Julieta de Almodóvar puede percibirse una matemática precisa en, por ejemplo, el trabajo de las estructuras del montaje combinando, como se verá en el epígrafe siguiente, el presente con distintos acontecimientos del pasado, como también una comunión con el paisaje tanto rural, a propósito del cortijo andaluz donde viven los padres de Julieta, como montañoso, al hilo del itinerario emprendido por la madre en busca de su hija, y finalmente, una notable expresividad escenográfica que se pone de manifiesto en las distintas cocinas que aparecen en el filme, según se ha visto en un epígrafe anterior. Curiosamente, en este mismo trabajo, Fernández- 
Galiano sitúa en Antonio López una referencia compartida por Higueras, pero en este caso a propósito no de la austeridad, como significaba Almodóvar, sino de "la exactitud rigurosa y talante figurativo que le hizo abrazar la herencia de Wright” (Fernández-Galiano, 2003, p. 6). Sea como sea, el hecho es que de ese homenaje que Julieta rinde al edificio de Higueras pueden extraerse, a partir de resaltar algunos de sus elementos comunes, interesantes diálogos entre las distintas obras.

\section{La construcción de la imagen almodovariana: iconografías del sexo y del rostro femenino}

Otra de las señas de identidad visual del cine de Almodóvar es el trazado de imágenes singulares, bien conformando programas iconográficos, esto es, conjuntos de imágenes diseminadas por el tejido textual, por lo general narrativamente deshilvanadas, que encierran en sus encuadres formas visuales vinculadas a un determinado tema o motivo común, como es el caso del sexo, o bien imágenes únicas, configuradoras en esta ocasión del rostro femenino.

En este sentido, Julieta va a construir, tomando como referencia la talla escultórica del hombre sedente que abre el filme, y ayudándose de otros soportes, así fotográficos, cinematográficos e incluso especulares, una singular iconografía del sexo. El prominente elemento fálico de la talla escultórica de partida invita, por mucho que enseguida la misma sea envuelta en plástico de burbujas, a una lectura en clave sexual que el propio filme hace suya. Y esto es algo que empieza a manifestarse al poco del arranque, cuando, recortándose sobre un fondo neblinoso, aparece la hermosa figura de un ciervo galopando jadeante por la nieve, en una imagen que, mostrada a través del cristal de la ventanilla de un tren, acaba siendo puesta en relación con la pareja de jóvenes, Xoan y Julieta, que acaba de conocerse:

- Xoan [refiriéndose al ciervo]: Espero que no se acerque mucho al tren.

- Julieta: No le da miedo el tren. Va buscando una hembra. La huele en el aire.

El ciervo cabalga desbocado en busca de esa hembra con la que va a copular. Tal es el enunciado que poco después encuentra su continuación en la propia pareja 
haciendo el amor, sus cuerpos reflejados en el cristal de la ventanilla del tren semejan el movimiento del ciervo cabalgando. Y así, la ventanilla del tren, actuando como marco que recorta al ciervo en su galope, primero, y como pantalla donde se refleja el galope de los cuerpos de la pareja, después, se descubre bisagra en torno a la cual se edifican estas dos nuevas referencias iconográficas del sexo.

Más adelante, otras imágenes vendrán a unirse a las anteriores para completar así el programa visual. Así las ya referidas que aparecen justo después de un nuevo coito de la pareja protagonista, imágenes ligadas, todas ellas, por una panorámica que parte de Julieta desnuda, tendida boca abajo en la cama, la cámara subrayando, en su movimiento, las líneas curvas de los muslos y de las caderas de la mujer, se continúa con Xoan, también desnudo y sentado en un sillón de la habitación, en una postura bien semejante a la del hombre representado en la escultura sedente, y que precisamente recoge inmediatamente después la panorámica, concluyendo esta con la incorporación de Ava, que modela en barro las nalgas de un cuerpo femenino desnudo tendido boca abajo. De manera que si anteriormente era la ventanilla de un tren el motivo que vinculaba las imágenes de los galopes del ciervo desbocado y de la pareja haciendo el amor, ahora es un movimiento de cámara, concretamente una prolongada panorámica, lo que, cosiendo una escena -la del dormitorio donde aparecen los cuerpos desnudos de la pareja- y otra -la del taller donde la escultura modeló el hombre sedente y modela ahora la mujer desnuda- vincula ambos pares de imágenes, quedando, de este modo, incorporadas, todas ellas, al programa iconográfico que nos ocupa. Finalmente, en una escena posterior, con motivo de la visita que Julieta hace a Ava en el hospital, un plano cercano muestra un photobook de la agencia internacional Magnum cuya portada exhibe la fotografía de una de las esculturas fálicas del hombre sedente ${ }^{12}$. El

12 Como título del libro aparece "Adiós volcán" y como autor "Lorenzo Gentille", en una operación por la que el filme se apropia tanto de la escultura de Navarro para asignársela a Ava, como del título del texto que el propio Almodóvar escribió como despedida a Chavela Vargas para asignárselo a Lorenzo Gentille, según un curioso entrecruzamiento de motivos que se ve aún más enriquecido cuando Chavela retorne, en este caso a través de su voz cantora, para clausurar el filme. Por demás, esta operación descubre a Lorenzo Gentille, además de como escritor, como estudioso de la obra de Ava. 
gesto de Julieta, subrayado por un plano detalle, pasando sus dedos por los genitales del tótem refuerza el elemento visual más destacado de una imagen, en este caso fotográfica, destinada a ampliar así este conjunto iconográfico que el filme despliega en torno al sexo.

Junto a esta operación anterior de construcción de imágenes, el filme va a realizar otra de semejante calado, en esta ocasión con motivo del trazado visual del rostro de la mujer protagonista. Almodóvar parecía tener claro, desde la concepción misma del filme, que el personaje de Julieta debía ser encarnado por dos actrices diferentes: "Es una opción que tuve muy clara desde el principio: tratar con dos actrices, pues no creo en el envejecimiento del personaje en el cine a través del maquillaje" (Creamer, 2016, s/p). Sin embargo, otros personajes, como Ava, por ejemplo, presente en el relato el mismo arco temporal que Julieta, sí es sometido a operaciones de maquillaje para mostrar en ella la mordida de la enfermedad y su prematuro envejecimiento. Fácil es inferir entonces que esta operación, novedosa en el cine de Almodóvar, apunta también en otra dirección. Por supuesto, no se trata aquí de un recurso como el trabajado por Luis Buñuel en Ese oscuro objeto del deseo (Cet obscur objet du désir, 1977), donde un mismo personaje, Conchita, era interpretado simultáneamente por dos actrices diferentes (Ángela Molina y Carole Bouquet), en un rasgo propio del surrealismo que incorpora el filme, sino que podría pensarse, más bien, en uno propio de las narraciones convencionales, en las que dos actrices de diferente edad encarnan al mismo personaje joven y adulto. Así, Adriana Ugarte interpretaría a la Julieta más joven, desde que conoce a Xoan, allí donde empieza la historia, hasta que es presa de los trastornos depresivos que le acarrean la muerte de aquel. Emma Suárez, por su parte, encarnaría a Julieta más madura, la que trata de recomponer su relación con Antía a través de la escritura de una carta en la que la culpa deviene en su motivo central. Si el rostro de Ugarte soporta el peso -y la culpa- de la muerte de Xoan, el de Suárez soportará el dolor que conlleva la separación de su hija huida. Pues bien: además de vincular a cada una de estas dos actrices con el período respectivo de la vida de Julieta antes señalado, el filme opta por mostrar la metamorfosis del rostro del personaje. Cabría pensar entonces, como es frecuente en Almodóvar, en el encadenado como la mejor opción discursiva para ello, un encadenado 
que, haciéndose cargo de la correspondiente elipsis temporal, asociara el tránsito del rostro a dos momentos diferentes de la vida de Julieta. Sin embargo, y es aquí donde se inscribe el mejor Almodóvar, el filme no opta por esta vía, sino que el rostro de Ugarte envuelto en una toalla deviene en el rostro de Suárez cuando la toalla es apartada. Las mismas imágenes desmienten que haya en tal transformación facial elipsis temporal alguna, por cuanto no sólo la toalla es la misma, sino que también el vestuario de las dos jóvenes presentes, pues son ellas quienes envuelven y desenvuelven la toalla, es idéntico. De manera que la mutación facial observada va vinculada no al paso del tiempo, sino al estado anímico del personaje, a su semblante, forjado a través de esta notable operación en la que la lisura del rostro de una Julieta abatida desaparece para alumbrar las materias del rostro lleno de surcos de una Julieta más serena y preparada para afrontar el dolor.

\section{Conclusión}

Nos encontramos ante un filme en el que se hacen visibles algunas de las constantes, tanto temáticas como formales, más características del discurso almodovariano. Así, la presencia recurrente de la cocina, hasta cinco distintas. Cinco cocinas de escenografías tan diferentes como cromáticamente llamativas -hasta el punto de que el color se convierte en el centro y motivo principal de la construcción visual de cada una de ellas- sobre las que se apoya tanto el recorrido de la protagonista cuanto la serie de acontecimientos que marcan su vida, desde la convivencia, marcada por la presencia de Ava, con Xoan y la desaparición de este, en Redes (Galicia), hasta el encuentro con su padre, en un cortijo de Mairena del Alcor (Andalucía), y pasando, tras una visita determinante a los padres de Bea, la amiga de Antía, por el traslado a Madrid, donde al dolor que aflora por la nueva pérdida, ahora de Antía, Julieta contrapone la huida a otra vivienda. Cinco cocinas, pues, que, además de convertirse en el sanctasanctórum de cada una de las casas, en expresión referida de Almodóvar, y de convertirse en lugares esenciales del relato, entran en correspondencia determinando una topografía tanto geográfica como biográfica y dramática, por cuanto inscriben el constante desequilibrio 
emocional que, a lo largo del trayecto geográfico y vital de Julieta, ha marcado su devenir personal.

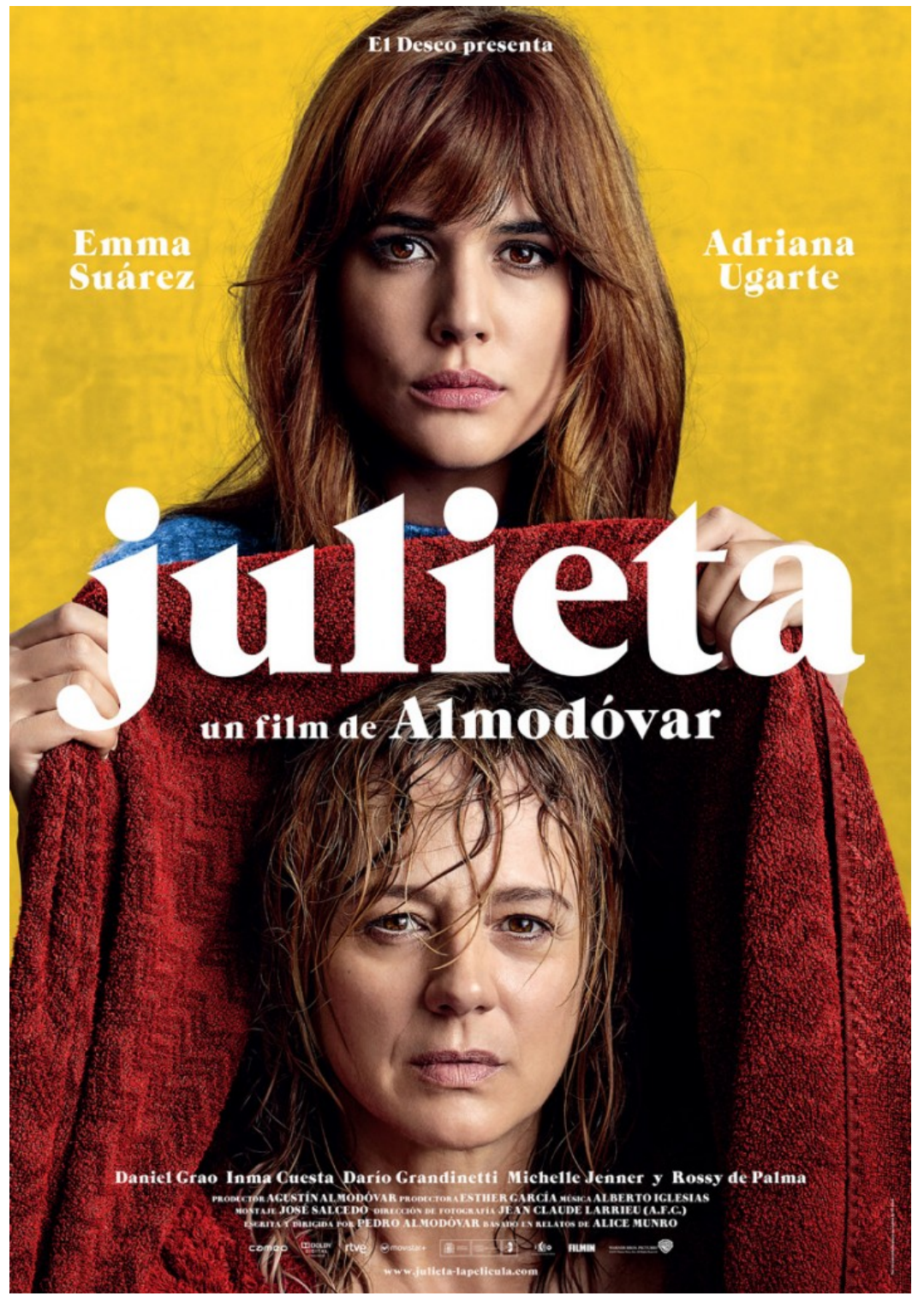

F8. Cartel de promoción de Julieta (Pedro Almodóvar, 2016). El Deseo

Además de descubrirse atravesada por la presencia de otros textos, así una talla escultórica de Miquel Navarro, una pintura de Lucien Freud, o una arquitectura de Fernando Higueras, entre otros, con los que se relaciona de manera bien diferente, Julieta forja iconografías singulares, así la emanada de la metamorfosis de un rostro femenino que es consecuencia del tránsito anímico de la mujer. Precisamente la pregnancia de esta mutación visual de un rostro, el de Adriana Ugarte, en otro, el de Emma Suárez, hizo que el diseñador Nico Bustos eligiera como motivo del cartel del filme esta misma dialéctica de los 
rostros de las dos actrices. Acudiendo en su caso a la iconografía cristiana, Bustos muestra a Ugarte desplegando una toalla y, como si del paño de la Verónica se tratara, en su tejido aparece impregnado el rostro de Suárez (F8). En una más que interesante operación de architextualidad, el cartel ofrece de este modo la imagen de una Julieta desdoblada exhibiendo su(s) cara(s) doliente(s): si el velo de la Verónica reflejaba el rostro de un hijo transido por el sufrimiento, el de la toalla de Missoni hace lo propio con el de una madre dolorosa.

\section{Referencias bibliográficas}

Almodóvar, P. (2016). Julieta. España: El Deseo.

Bastida de la Calle, M. D. (1996). La mujer en la ventana: una iconografía del XIX en pintura e ilustración. Espacio, Tiempo y Forma, serie VII, Historia del Arte, 9, 297-315.

Bermejo, A. G. (2016). El hombre que amaba a las mujeres. Entrevista con Pedro Almodóvar. Dirigido por, 465, 84-88.

Camarero Gómez, G. (2017). Literatura y Arte en Julieta de Pedro Almodóvar. DeSignis, 27, 45-52.

Creamer, D. (2016). Almodóvar: "Impregné Julieta de la soledad en la que he vivido estos años". Infolibre, 21 de mayo de 2016. Recuperado de https://www.infolibre.es/noticias/cultura/2016/05/21/almodovar quot impregne_julieta_soledad_que_vivido_estos_anos_quot_50059_1026.h tml.

Fernández-Galiano, L. (2003). De la colina de los chopos al monte de las encinas. Boletín de actividades "Estudio", 10, 4-9.

Fernández-Santos, E. (2016). Julieta, el drama más seco de Almodóvar. El País Semanal, 2060, 20 de marzo de 2016, 23-27.

Gardies, A. (1993). L'Espace au cinema. Paris: Méridien Klincksieck.

Labastida, M. (2016). Las esculturas de Miquel Navarro seducen a Pedro Almodóvar. Las Provincias, 14 de febrero de 2016. Recuperado de https://www.lasprovincias.es/culturas/201602/11/esculturas-miquelnavarro-seducen-20160211001303-v.html.

Martínez, L. (2016). Pedro Almodóvar: "El dolor exige discreción”. El Mundo, 4 de abril de 2016. Recuperado de http://www.elmundo.es/cultura/2016/04/04/56fe949c268e3ef5148b4 674.html.

Moliner, M. (2001). Diccionario de uso del español, $A-H, 2^{\text {a }}$ edición. Madrid: Gredos. 
Poyato, P. (2015). Identidad visual y forma narrativa en el drama cinematográfico de Almodóvar. Madrid: Síntesis.

Ramón, E. (2016). Pedro Almodóvar: “Julieta refleja la soledad deliberada en la que vivo ahora mismo". Noticias Cultura RTVE. Recuperado de http://www.rtve.es/noticias/20160404/pedro-almodovar-julieta-reflejasoledad-deliberada-vivo-ahora-mismo/1329187.shtml.

Seguin, J.-C. (2009). Pedro Almodóvar o la deriva de los cuerpos. Murcia: Filmoteca de Murcia.

Zabalbeascoa, A. (2019). Piedad Bonnett: "Escribir desde las tripas el algo femenino”. El País Semanal, 2.206, 46-51. 